\title{
Relationship between early pregnancy factor, mouse embryo-conditioned medium and platelet-activating factor
}

\author{
A. C. Cavanagh, B. E. Rolfe, S. Athanasas-Platsis, K. A. Quinn and \\ H. Morton \\ Department of Surgery, University of Queensland, Royal Brisbane Hospital, Brisbane, Qld 4029, \\ Australia
}

\begin{abstract}
Summary. The effects of synthetic platelet-activating factor (PAF-acether) and mouse embryo-conditioned medium (a source of embryo-derived PAF (EPAF)) on production of early pregnancy factor (EPF) were compared. Embryo-conditioned medium, itself inactive in the EPF bioassay, stimulated ovarian production of EPF in vitro but PAF-acether did not. In vivo, embryo-conditioned medium induced EPF activity in serum of oestrous female, but not in male, mice in contrast to PAF-acether, which induced activity in serum of both male and female mice. This PAF-induced activity was transitory, declining significantly by $2 \mathrm{~h}$ and disappearing by $3 \mathrm{~h}$ after injection. Activity induced by embryo-conditioned medium was first evident at $2 \mathrm{~h}$ after injection, serum concentrations increasing up to $6 \mathrm{~h}$ after injection. By discriminating between the behaviour of PAF-acether and EPAF, these studies reinforce the conclusions of other workers that the molecule produced by the embryo is not PAF. Further investigations into the mechanism of action of PAF-acether revealed that it is a potent inducer of activity in the EPF bioassay, with an absolute requirement for platelets in the spleen cell suspension used in the assay. This platelet-derived active species was bound specifically by an anti-EPF monoclonal antibody, indicating that it is EPF-like. This is consistent with parallel studies showing that platelets are not required for induction of activity by either pregnancy serum or purified EPF. These studies were applied to the PAF-induced leukotriene-like species, which had been found by others to be active in the EPF bioassay. Pregnancy serum induced the appearance of this substance from the spleen cell suspension used in the assay; thus the leukotriene-like substance may be regarded as an effector molecule in vitro or mediator of the initiating stimulus of EPF in the bioassay.
\end{abstract}

Keywords: early pregnancy factor; platelet-activating factor; rosette inhibition test; leukotriene; mouse

\section{Introduction}

Maternal recognition of pregnancy is classically regarded as first occurring in the peri-implantation period, but communications commencing at virtually the time of fertilization have been identified. These include early pregnancy factor (EPF), produced by the maternal ovary within $6 \mathrm{~h}$ of fertilization in response to an embryonic signal, termed ovum factor (Morton et al., 1980, 1987; Cavanagh et al., 1982, 1991), and embryo-derived, platelet-activating factor (EPAF), detectable within $10 \mathrm{~h}$ of mating by its induction of mild maternal thrombocytopaenia (O'Neill, 1985a, b). It has been suggested that ovum factor and EPAF have similar properties and thus that these two early events in mammalian pregnancy may be linked (O'Neill, 1985c). Studies by Orozco et al. (1986) showing that EPF production was stimulated in nonpregnant female, but not in male, mice within $1 \mathrm{~h}$ of injection with synthetic platelet-activating factor (PAF-acether) and by Sueoka et al. (1988) 
demonstrating stimulation of EPF production by PAF-acether in vivo and in vitro support the proposition. Orozco et al. (1990) and Clarke et al. (1990) have extended their studies to show that PAF-acether and oestrous mouse serum, combined in vitro, were sufficient to generate activity in the EPF bioassay, the rosette inhibition test. They imply that the EPAF and EPF systems are coincidental rather than linked.

Several recent studies, however, have called into question the relationship between EPAF and PAF. Amiel et al. (1989) failed to demonstrate PAF activity in medium conditioned by human embryos using the washed rabbit-platelet-aggregation bioassay; Smal et al. (1990), using the same bioassay, also failed to detect PAF activity in mouse embryo-conditioned medium. Smal et al. were unable to detect PAF in medium conditioned by mouse embryos using a highly specific and sensitive radioimmunoassay capable of detecting $\geqslant 1 \mathrm{pg}$ PAF/embryo. They concluded that embryos do not produce significant quantities of PAF or of one of the biologically active analogues of PAF. Thus, experimental results obtained with PAF-acether substituting for EPAF must be seriously questioned.

These conclusions, with our recent studies on mechanisms involved in the bioassay for EPF, the rosette inhibition test (Rolfe et al., 1988, 1989; Cavanagh et al., 1991), prompted a re-examination of experiments suggesting that EPAF and EPF are linked. The effects of PAF-acether and mouse embryo-conditioned medium (a source of both EPAF and ovum factor) on EPF production, in vivo and in vitro, were therefore compared in this study.

\section{Materials and Methods}

\section{Mice}

Male and virgin female BALB/c, C57BL/6 and Quackenbush mice, 6-8 weeks old (Central Animal Breeding House, University of Queensland, Brisbane, Australia) were housed in a room with $12 \mathrm{~h}$ light:12 h dark at $22-26^{\circ} \mathrm{C}$ with free access to water and mouse pellets. The stage of oestrus of female mice was monitored by vaginal smear (Rugh, 1968). Females in oestrus were caged overnight with males (1:1) and mating was confirmed next morning by the presence of a vaginal plug (Day 1). Where indicated, Quackenbush female mice were superovulated by i.p. injection of $10 \mathrm{iu}$ of each of pregnant mares' serum gonadotrophin (Folligon: Intervet, Melbourne, Australia) and human chorionic gonadotrophin (Pregnyl: Organon, Morden, UK) given $\sim 48 \mathrm{~h}$ apart; ovulation occurs $12-16 \mathrm{~h}$ later (Edwards \& Gates, 1959).

\section{Embryo-conditioned medium}

Oviducts were excised from Quackenbush mice on Day 2 of pregnancy and embryos flushed and washed with Dulbecco's modified Eagle's medium (DMEM; Flow Laboratories, Irvine, UK) containing $1 \mathrm{mg}$ bovine serum albumin (BSA: Sigma Chemical Co., St Louis, MO, USA), 100 U penicillin (CSL: Melbourne, Australia) and $100 \mathrm{mg}$ streptomycin (Sigma)/ml. Groups of ten 2-cell embryos were placed in $0.2 \mathrm{ml}$ of the culture medium in 96-well microtitre plates (Nunclon, Nunc, Denmark) and incubated at $37^{\circ} \mathrm{C}$ for $24 \mathrm{~h} \mathrm{in} 5 \% \mathrm{CO}_{2}$ in air. Embryos were then removed and conditioned medium was stored under sterile conditions at $4^{\circ} \mathrm{C}$ and used within $2-3$ days.

\section{MEPF}

EPF was purified from medium conditioned by oestrous mouse ovaries and from oviducts stimulated with prolactin and medium conditioned by mouse embryos, as described by Cavanagh (1984).

\section{PAF-acether}

A stock solution of $1 \mathrm{mg}$ PAF-acether (1-0-hexadecyl-2-0-acetyl-sn-glycero-3-phosphocholine; Sigma)/ml in absolute ethanol was prepared and stored at $-30^{\circ} \mathrm{C}$. For in-vivo experiments, this solution was diluted in $0.9 \%(\mathrm{w} / \mathrm{v})$ sodium chloride containing $0.01 \%(\mathrm{w} / \mathrm{v}) \mathrm{BSA}$; for in-vitro experiments, it was diluted in Hank's balanced salt solution, without calcium or magnesium containing $0.01 \%(w / v)$ BSA (HBSS and BSA).

\section{Preparation of supernatants S1 and S2}

Following the terminology and methods of Orozco et al. (1990), these supernatants were prepared by incubation of $1.5 \times 10^{7}$ spleen cells with $0.2 \mathrm{ml}$ inducing substance (PAF-acether or pregnancy serum) for $0.5 \mathrm{~h}$ at $37^{\circ} \mathrm{C}$. 
Cells were then pelleted, supernatant SI was removed and the cells were washed twice with HBSS. They were then resuspended in $0.2 \mathrm{ml} \mathrm{HBSS}$, incubated for a further $0.5 \mathrm{~h}$ at $37^{\circ} \mathrm{C}$ and pelleted and supernatant $\mathrm{S} 2$ was removed.

\section{Bioassay for EPAF}

The assay was performed according to the method of O'Neill (1985b). Blood was sampled from the periorbital plexus of splenectomized mice under light halothane anaesthesia and $30 \mu \mathrm{l}$ was diluted into $3 \mathrm{ml} 1 \%(\mathrm{w} / \mathrm{v})$ ammonium oxalate, mixed and spread on both sides of a haemocytometer. Mice were then injected i.p. with $200-300 \mu 1$ of either culture medium alone, embryo-conditioned medium or PAF-acether $(2.5 \mu \mathrm{g} / \mathrm{ml})$. Thirty minutes after injection, blood was obtained and treated as described. Twenty minutes after spreading, platelets were counted using phase-contrast microscopy; samples were assayed in duplicate.

\section{Bioassay for EPF: the rosette inhibition test}

This assay is dependent on the finding that lymphocytes, preincubated in pregnancy serum or EPF, give a significantly higher rosette inhibition titre (RIT) with an antilymphocyte serum (ALS) than lymphocytes from the same donor without EPF (Morton et al., 1974, 1976).

The assay was performed with spleen cells from male mice, rabbit antimouse lymphocyte serum and human red blood cells (Rolfe et al., 1984; Morton et al., 1987); positive (mouse pregnancy serum) and negative (HBSS and BSA) controls were included with each set of tests. The RIT of the ALS used in these studies, expressed as $\log _{2}$ (reciprocal dilution of ALS $\times 10^{-3}$ ) was 10 ; an RIT $\geqslant 16$ was positive for EPF and an RIT <16 was negative (see Morton et al., 1987). The assay is basically nonquantitative, but may be used in a semiquantitative manner by comparing the limiting positive dose of samples (bearing in mind the caveat discussed in Cavanagh et al., 1991). Results, therefore, are frequently reported as limiting dose, the highest dilution of a sample giving a positive assay. HBSS and BSA was used for preparation of all sample dilutions.

Spleen cells from outbred mice were used, except when testing for EPF-induced, genetically restricted suppressor factors, when samples were incubated with spleen cells from syngeneic (BALB/c) and allogeneic (C57BL/6) mice. A positive result with syngeneic and allogeneic cells indicated the presence of EPF; a positive result with only syngeneic cells indicated the presence of suppressor factors (Rolfe et al., 1988).

\section{Relationship between embryo-conditioned medium, PAF-acether and EPF}

Ovarian stimulation in vitro. These studies followed the methods described by Cavanagh et al. $(1982,1991)$. Ovaries were removed from superovulated Quackenbush mice, washed extensively with DMEM and incubated in DMEM overnight to remove entrapped blood. After further washing, a single ovary was incubated for $24 \mathrm{~h}$ at $37^{\circ} \mathrm{C}$ in $0.2 \mathrm{ml}$ embryo-conditioned medium, with and without prolactin (100 ng rat prolactin, PRL-6, NIH, Bethesda, USA; Cavanagh et al., 1982). Parallel cultures were prepared with $0.2 \mathrm{ml} \mathrm{PAF}$-acether $(100 \mathrm{pg} / \mathrm{ml}$ in DMEM) or DMEM alone substituting for embryo-conditioned medium. Supernatants were dialysed overnight against HBSS to remove substances used for stimulation and then tested in the rosette inhibition test in 10 -fold dilutions from $10^{-1}$ to $10^{-6}$. The studies were performed in triplicate.

Activity in vivo. Male and oestrous female BALB/c mice were injected i.p. with either $1 \mathrm{ng}$ PAF-acether or $0.25 \mathrm{ml}$ embryo-conditioned medium, shown to have activity in the bioassay for EPAF. Control groups were injected i.p. with either $0.1 \mathrm{ml} 0.9 \% \mathrm{NaCl}$ and $0.01 \%$ BSA or $0.25 \mathrm{ml}$ culture medium alone. Blood was sampled from groups of 3 under halothane anaesthesia by cardiac puncture or from the periorbital plexus $1,2,4$ and $6 \mathrm{~h}$ after injection. Serum was inactivated at $56^{\circ} \mathrm{C}$ for $0.5 \mathrm{~h}$ and stored at $-30^{\circ} \mathrm{C}$ prior to testing in the rosette inhibition test, diluted 1 in 4 and in 10 -fold dilutions from $10^{-1}$ to $10^{-8}$.

Activity in the rosette inhibition test. Embryo-conditioned medium and PAF-acether $(1 \mu \mathrm{g} / \mathrm{ml})$, with and without $10 \%$ oestrous mouse serum, were tested in the rosette inhibition test at dilutions from 1 in 4 to $10^{-12}$, as was the supernatant $\mathrm{SI}$ induced from spleen cells by $5 \mathrm{nmol}$ PAF/1. Studies were performed in duplicate.

\section{Mechanism of action of PAF-acether in the EPF bioassay}

Cell preparation. Spleen cell suspensions $\left(2 \times 10^{7}\right.$ cells $/ \mathrm{ml}$ in HBSS) were prepared as described by Rolfe et al. (1984). Platelet depletion was carried out by centrifugation at $200 \mathrm{~g}$ for $15 \mathrm{~min}$ on a $20 \%(\mathrm{w} / \mathrm{v})$ sucrose gradient. The pellet containing lymphoid cells was resuspended and subjected to a second gradient separation. The resulting preparation was examined by phase-contrast microscopy to determine the efficacy of the procedure.

Platelets were prepared from spleen cell suspensions by centrifugation at $200 \mathrm{~g}$ for $15 \mathrm{~min}$ followed by recentrifugation of the supernatant at $900 \mathrm{~g}$ for $15 \mathrm{~min}$; for platelet preparation, spleen cell suspensions were not subjected to red cell lysis.

Preparation of supernatants. PAF-acether $\left(0.4 \mathrm{ml}, 100 \mathrm{pg} / \mathrm{ml}\right.$, in HBSS and BSA) was incubated at $37^{\circ} \mathrm{C}$ for $0.5 \mathrm{~h}$ with (a) total spleen cells $\left(4 \times 10^{7}\right.$ cells $)$, (b) platelet-depleted spleen cells $\left(4 \times 10^{7}\right.$ cells $)$, (c) platelets $\left(2 \times 10^{8}\right)$ or $(\mathrm{d})$ a 
recombinant of (b) and (c). The mixtures were then centrifuged at $900 \mathrm{~g}$ for $15 \mathrm{~min}$, supernatants were collected and PAF-acether was removed either by overnight dialysis against 2 changes of HBSS or by passage through a Sephadex G-25 desalting column (PD-10, Pharmacia-LKB, Uppsala, Sweden), previously equilibrated with HBSS and BSA; since PAF can bind to BSA (Clay et al., 1990), PAF-acether alone $(0.4 \mathrm{ml}, 100 \mathrm{pg} / \mathrm{ml}$, in HBSS and BSA) was treated similarly to check the efficiency of the removal techniques. Parallel incubations were carried out with mouse EPF (mEPF) $\left(100 \mathrm{pg} / \mathrm{ml}\right.$ in HBSS and BSA; Cavanagh, 1984), Day-10 mouse pregnancy serum $\left(10^{-5}\right.$ in HBSS and BSA) and HBSS and BSA alone. Supernatants and treated PAF-acether solutions were then tested in the rosette inhibition test undiluted and in 10-fold dilutions to $10^{-6}$; studies were performed in duplicate.

Immunoabsorption of supernatants. An anti-EPF immunoabsorbant was prepared from mouse monoclonal antiEPF immunoglobulin M (IgM; 5/341, characterized in vivo and in vitro; Athanasas-Platsis et al., 1989; Quinn et al., 1990) coupled to CNBr Sepharose ( $2 \mathrm{mg} \mathrm{IgM/ml} \mathrm{gel)} \mathrm{according} \mathrm{to} \mathrm{the} \mathrm{manufacturer's} \mathrm{instructions} \mathrm{(Pharmacia-}$ LKB). A control gel was prepared with normal mouse serum.

Supernatants $(0.5 \mathrm{ml})$, produced by incubation of platelet-depleted spleen cells with Day-10 mouse pregnancy serum $\left(10^{-5}\right.$ in HBSS and BSA), or platelets with PAF-acether, were absorbed by mixing (separately) end-over-end for $1 \mathrm{~h}$ at room temperature with anti-EPF and control immunoabsorbent gels $(0 \cdot 2 \mathrm{ml})$ which had been equilibrated with phosphate-buffered saline (PBS) $0.01 \%$ BSA. The mixtures were then centrifuged, supernatants removed (unbound fraction), gels washed twice with PBS and eluted with $0.5 \mathrm{ml}$ glycine-HCl buffer $(0.2 \mathrm{~mol} / \mathrm{l})$ at $\mathrm{pH} 2.4$ (bound fraction). Bound and unbound fractions were exchanged into HBSS and BSA by passage through PD-10 columns and tested in the rosette inhibition test at dilutions from $10^{-1}$ to $10^{-6}$; studies were performed in duplicate.

Extraction of pregnancy serum and pregnancy-serum-induced $\mathbf{S 2}$ factors. These studies followed the 2-stage lipid extraction technique of Clancy \& Hugli (1983) as applied by Clarke et al. (1990) to the supernatant S2, induced from spleen cells by $5 \mathrm{nmol}$ PAF/l, but substituted Day-10 mouse pregnancy serum $\left(10^{-3}\right.$ in PBS and BSA) for PAF. Siliconized glassware was used throughout. A $0.5 \mathrm{ml}$ aliquant of diluted serum was extracted with isopropanol, formic acid $(5 \mathrm{~mol} / \mathrm{l})$ and ether $(0 \cdot 5: 0 \cdot 03: 1 \cdot 5)$. The aqueous and organic phases were then separated and $\sim 50 \mu \mathrm{l}$ at the interface was discarded; the aqueous phase $(\sim 0.5 \mathrm{ml})$ was adjusted to $\mathrm{pH} 7 \cdot 0$. After addition of 0.015 volumes of $\mathrm{NH}_{4} \mathrm{OH}$ $(10 \mathrm{~mol} / \mathrm{l})$, the organic phase was evaporated with a stream of $\mathrm{N}_{2}$, the tube rinsed twice with PBS and the residue dissolved in $0.5 \mathrm{ml}$ methanol and chloroform (1:1). This was resolved into polar and nonpolar phases by addition of $0.22 \mathrm{ml} \mathrm{NH}{ }_{4} \mathrm{OH}(10 \mathrm{mmol} / \mathrm{l})$. The phases were separated and again $50 \mu \mathrm{l}$ at the interface was discarded. Methanol was evaporated from the polar phase with a stream of $\mathrm{N}_{2}$ and the remaining aqueous mixture made up to $0.5 \mathrm{ml}$ with PBS and BSA. The nonpolar phase was evaporated with a stream of $\mathrm{N}_{2}$ and the residue dissolved in $50 \mu \mathrm{l} 65 \%$ methanol and $0.1 \%$ acetic acid at $\mathrm{pH} 5.6$. The first aqueous, second aqueous and second organic phases were then tested in the rosette inhibition test in 10 -fold dilutions.

The experiment was repeated with $0.5 \mathrm{ml}$ supernatant $\mathrm{S} 2$ induced from spleen cells by Day-10 mouse pregnancy serum $\left(10^{-3}\right.$ in HBSS and BSA). Both studies were performed in duplicate.

\section{Results}

\section{In-vitro production of EPAF by 2-cell embryos}

Culture medium alone did not affect the number of platelets when injected into splenectomized mice. Medium conditioned by 2 -cell embryos induced a $37 \%$ reduction in number of platelets; the reduction observed after injection of PAF-acether was $23 \%$.

\section{Relationship between embryo-conditioned medium, PAF-acether and EPF}

Ovarian stimulation in vitro. EPF activity was detected in supernatants from ovaries incubated with embryo-conditioned medium in the presence of $100 \mathrm{ng} / 0.2 \mathrm{ml}$ prolactin (limiting dose $10^{-5}$ ), but not in supernatants from ovaries incubated with PAF-acether, either in the presence or absence of prolactin or with the negative control medium.

Activity in vivo. Serum from male and female mice was active in the rosette inhibition test at $1 \mathrm{~h}$ after injection with PAF-acether (Fig. 1). The difference in limiting dose of male $\left(10^{-5}-10^{-6}\right)$ and female $\left(10^{-3}\right)$ sera is consistent with the presence of an oestrous-dependent inhibitor (Cavanagh $e t$ al., 1991), which substantially reduces the response of EPF in the rosette inhibition test. The difference probably explains also the failure of Orozco et al. (1986) to detect activity in male sera after injection with PAF; dilutions beyond those observed to be positive with female sera were not tested.

This PAF-induced activity was transitory (Fig. 2). By $2 \mathrm{~h}$ after injection, the limiting dose of male and female sera was declining and, by $4 \mathrm{~h}$, no activity was detected. This contrasts with the 


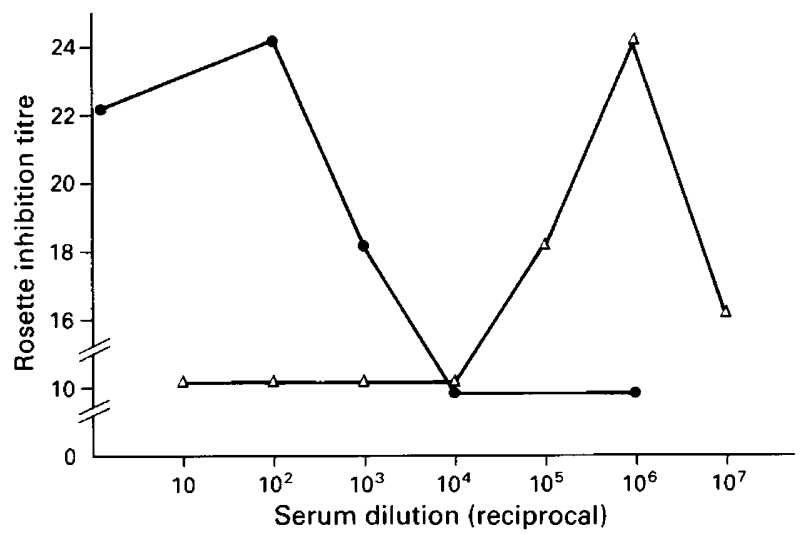

Fig. 1. Activity in the rosette inhibition test of sera of male $(\triangle)$ and oestrous female $(\bullet)$ mice $1 \mathrm{~h}$ after injection with $1 \mathrm{ng}$ platelet-activating factor. Rosette inhibition titres $\geqslant 16$ indicate a positive response.

time-course of activity induced by embryo-conditioned medium: $1 \mathrm{~h}$ after it was injected, serum from male and oestrous female mice had no activity in the rosette inhibition test. At $2 \mathrm{~h}$ after injection, a positive result was obtained with serum from 1 of 3 oestrous female mice and, at 4 and $6 \mathrm{~h}$, all oestrous females were positive. No activity was detected in serum from male mice at any time after injection. Thus PAF-acether appears to be acting by a different mechanism from embryo-conditioned medium, prompting investigation of the possibility that PAF-acether acts directly on spleen cells, altering their activity in the rosette inhibition test.

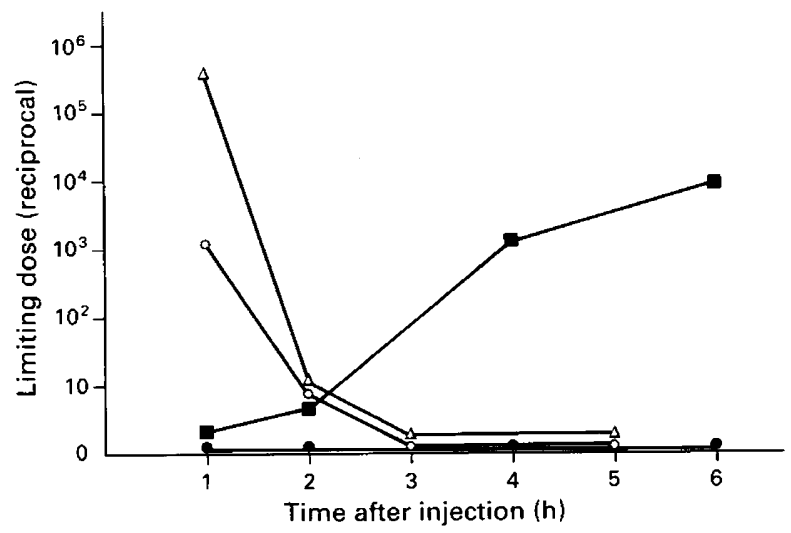

Fig. 2. Activity in the rosette inhibition test of sera of male and oestrous female mice at various times after injection of $1 \mathrm{ng}$ platelet-activating factor (PAF) or medium conditioned by 2-cell mouse embryos (ECM; equivalent of $\sim 10$ embryos); $(\triangle)$ male, PAF; $(O)$ female, PAF; $(\odot)$ male, ECM; ( $\mathbf{a})$ female, ECM. Results are expressed as limiting dose, the highest dilution of sample giving a positive assay.

Activity in the rosette inhibition test. Embryo-conditioned medium, positive for EPAF in the splenectomized mouse bioassay, had no activity in the rosette inhibition test, with or without the addition of oestrous mouse serum.

In contrast, in the presence of $10 \%$ oestrous serum, PAF-acether was active in the rosette inhibition test from $20 \mathrm{pmol} / \mathrm{l}$ to $2 \mathrm{nmol} / \mathrm{l}$ (Fig. 3), consistent with the observations of Orozco et al. (1990). Contrary to their findings, PAF-acether was active also in the absence of oestrous serum; 
the region of response shifted to $0.02-0.5 \mathrm{fmol} / \mathrm{l}$, an activity threshold 4 times lower than the lowest dilution tested by Orozco et al. $(1986,1990)$. Once again, the apparently negative results obtained by these authors in the absence of the oestrous-dependent inhibitor can be attributed to their failure to test at sufficiently high dilution.

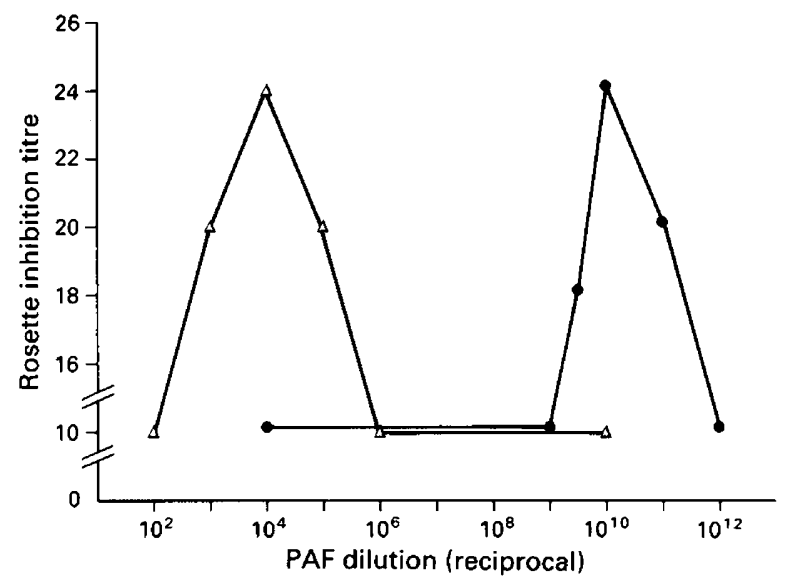

Fig. 3. Activity in the rosette inhibition test of platelet-activating factor (PAF), with $(\triangle)$ and without $(\bullet) 10 \%$ oestrous mouse serum, starting concentration $2 \mu \mathrm{mol} / 1$. Rosette inhibition titres $\geqslant 16$ indicate a positive response.

As would be expected from these results, the supernatant S1, induced from spleen cells by $5 \mathrm{nmol}$ PAF-acether/l, and studied extensively by Orozco et al. (1990) in an attempt to explain its apparent activity only in the presence of oestrous serum, was active in the presence and absence of oestrous serum (Fig. 4).

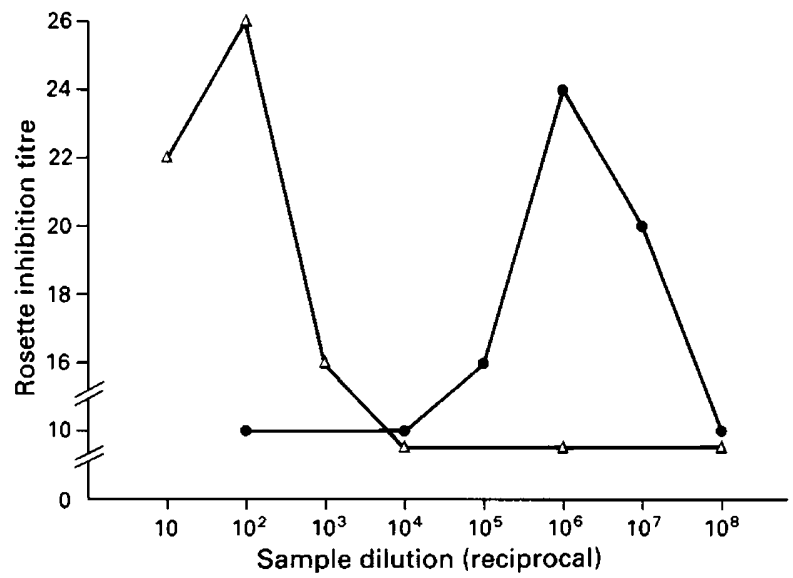

Fig. 4. Activity in the rosette inhibition test of supernatant $\mathrm{S} 1$ induced by $5 \mathrm{nmol} P A F / 1$, with $(\triangle)$ and without $(\bullet) 10 \%$ oestrous mouse serum. Rosette inhibition titres $\geqslant 16$ indicate a positive response.

\section{Mechanism of action of PAF-acether in the EPF bioassay}

Desalting techniques employed in these experiments effectively removed PAF under the conditions described. After treatment, a PAF-acether solution (100 pg/ml in HBSS and BSA) which, as 
shown in Fig. 3, should have activity in the EPF bioassay at a limiting dose of $\sim 10^{-5}$ had no activity up to a dilution of $10^{-6}$.

Supernatants, produced by incubation of PAF-acether and spleen cells $(100 \mathrm{pg} / \mathrm{ml}$, limiting dose $10^{-5}$ ) and desalted to remove PAF, still displayed activity (limiting dose $10^{-5}$ ), suggesting that PAF might be stimulating production of an active substance. Since supernatants were positive (to the same limiting dose) with syngeneic (BALB/c) and allogeneic (C57BL/6) spleen cells, this could not be due to direct stimulation of the genetically restricted suppressor factors which Rolfe et al. (1988) have shown to be the active species induced by EPF.

Further experiments (Table 1) were conducted to examine the role of platelets in induction of this active substance by PAF-acether. These used supernatants from various PAF-stimulated cell preparations, desalted to remove PAF, prior to testing with fresh spleen cells. Supernatants produced by incubation of platelet-depleted spleen cell preparations with PAF-acether had no activity in the rosette inhibition test. In contrast, positive results were obtained with supernatants from incubation of platelet-reconstituted spleen cells with PAF and from platelets alone with PAF, indicating that platelets are required for PAF-induced activity in the rosette inhibition test. This is in contrast to activity associated with EPF; platelet-depleted and total spleen cell preparations gave identical results when incubated with purified EPF or Day-10 mouse pregnancy serum.

Table 1. Role of platelets in induction of activity in the rosette inhibition test by platelet-activating factor (PAF)

\begin{tabular}{lcccc}
\hline & \multicolumn{4}{c}{ Cell population stimulated* } \\
\cline { 2 - 5 } Stimulator & $\begin{array}{c}\text { Total spleen } \\
\text { cells }\end{array}$ & $\begin{array}{c}\text { Platelet-depleted } \\
\text { spleen cells }\end{array}$ & $\begin{array}{c}\text { Platelet-reconstituted } \\
\text { spleen cells }\end{array}$ & Platelets \\
\hline PAF $(100 \mathrm{pg} / \mathrm{ml})$ & + & - & + & + \\
Day- 10 mouse pregnancy & + & + & + & ND \\
serum $\left(10^{-5}\right)$ & + & + & + & ND \\
mEPF $(100 \mathrm{pg} / \mathrm{ml})$ & + & & + & +
\end{tabular}

*Cell population incubated with stimulator for $0.5 \mathrm{~h}$ at $37^{\circ} \mathrm{C}$, cells pelleted, supernatant dialysed overnight and tested in the rosette inhibition test with a fresh total spleen cell suspension; + indicates a positive and - a negative result in this assay; ND, not done.

Platelets were not required for induction of the genetically restricted suppressor factors (Table 2). Supernatants from platelet-depleted spleen cells, incubated with pregnancy serum and subjected to immunoabsorption to remove the inducing EPF, gave a positive result with freshly prepared syngeneic (BALB/c) but not allogeneic (C57BL/6) spleen cells (i.e. positive for suppressor factors, but not for EPF; see Rolfe et al., 1988). Taken together, these experiments suggested that the active substance(s) released by platelets in response to PAF might be EPF-like. This was confirmed (Table 2) by immunoabsorption experiments with an anti-EPF monoclonal antibody. The activity of PAF-induced platelet supernatant, desalted to remove PAF, was removed by immobilized monoclonal anti-EPF IgM (but not by control gels) and recovered almost quantitatively by treatment with buffer at $\mathrm{pH} 2 \cdot 4$, indicating specific recognition of the active species by this antibody.

Extraction of pregnancy serum and pregnancy-serum-induced $\boldsymbol{S 2}$ factors. To reconcile these results with the studies of Clarke et al. (1990), which characterized the PAF-induced active S2 factors as leukotriene-like, the same lipid extraction technique was applied to the archetypal source of EPF, pregnancy serum, and to pregnancy-serum-induced S2 factors. The activity of pregnancy serum was extracted into the first aqueous phase, where proteins partition (Fig. 5a); activity was not found in the lipid fraction and removal of lipid appeared to enhance activity of the aqueous fraction significantly. This contrasts with activity displayed by pregnancy-serum-induced $\mathrm{S} 2$ factors (Fig. 5b). While activity was still observed in the first aqueous (protein) phase, (indicating the 
Table 2. Relationship between active species induced by early pregnancy factor (EPF) and platelet-activating factor (PAF)

\begin{tabular}{|c|c|c|c|}
\hline Supernatant from & $\begin{array}{l}\text { Treatment with } \\
\text { immobilized anti-EPF }\end{array}$ & Test cells & Result* \\
\hline $\begin{array}{l}\text { Platelet-depleted BALB/c spleen cells } \\
\quad+\text { Day-10 mouse pregnancy serum }\left(10^{-5}\right)\end{array}$ & $\begin{array}{l}- \\
+\end{array}$ & $\begin{array}{l}\text { BALB/c } \\
\text { C } 57 B L / 6 \\
\text { BALB/c } \\
\text { C } 57 B L / 6\end{array}$ & $\begin{array}{l}+ \\
+ \\
+ \\
-\end{array}$ \\
\hline BALB $/ \mathrm{c}$ platelets + PAF $(100 \mathrm{pg} / \mathrm{ml})$ & $\begin{array}{l}- \\
+\end{array}$ & $\begin{array}{l}\text { BALB/c } \\
\text { C } 57 B L / 6 \\
\text { BALB/c } \\
\text { C57BL } / 6\end{array}$ & $\begin{array}{c}+ \\
+ \\
- \\
\text { ND }\end{array}$ \\
\hline
\end{tabular}

${ }^{*}$ Supernatants from incubation of indicated cells with pregnancy serum or PAF for $0.5 \mathrm{~h}$ at $37^{\circ} \mathrm{C}$, were dialysed and tested in the rosette inhibition test with syngeneic (BALB/c) and allogeneic (C57BL/6) spleen cells, either directly or after immunoabsorption with monoclonal anti-EPF; + indicates a positive and - a negative result in this assay; ND, not done.

presence of suppressor factors), the bulk of activity appeared in the second aqueous (polar leukotriene) phase, in a similar pattern to that observed by Clarke et al. (1990) for PAF-induced S2 factors. Clarke also observed activity in the second organic (nonpolar lipid) phase of this PAFinduced preparation. This is almost certainly attributable to the continuing presence of PAF (see Clancy \& Hugli, 1983; Orozco et al., 1990); when pregnancy serum was used as inducer, no activity was detected in this phase. These results are consistent with, and a logical extension of, the studies above indicating that the primary action of PAF in the rosette inhibition test is the induction of EPF release by platelets in the spleen cell suspension used in the assay.

\section{Discussion}

Some aspects of the relationship between PAF, embryo-conditioned medium and EPF have been clarified by these studies. As in previous investigations, (Morton et al., 1980, 1987; Cavanagh et al., 1982, 1991), embryo-conditioned medium (a source of both ovum factor and EPAF), itself inactive in the EPF bioassay, stimulated ovarian production of EPF in vivo and in vitro. In contrast, PAF did not stimulate EPF production by the ovary in vitro; in vivo, it induced EPF activity in serum of male and female mice. Thus, a third assay system has been described which can discriminate between the behaviour of EPAF and PAF, reinforcing the conclusion of Amiel et al. (1989) and Smal et al. (1990) that the molecule produced by the embryo is not PAF.

The finding that PAF induces activity in the serum of male as well as female mice raises the question of the source of this activity. A detailed series of studies on the effect of PAF on the spleen cell preparations used in the EPF bioassay helped to clarify this aspect and revealed an unexpected involvement of platelets with EPF. PAF itself was an extraordinarily potent inducer of activity in the bioassay with an absolute requirement for platelets in the spleen cell suspension, but platelets were not required for induction of activity by either pregnancy serum or purified EPF, leading to the consideration that this platelet-derived active species might, in fact, be EPF. Further investigations were conducted with a well-characterized monoclonal anti-EPF antibody; this specifically bound the platelet-derived species indicating that it is EPF-like.

The work of Orozco et al. (1986, 1990) and Clarke et al. (1990) must be re-interpreted in the light of these findings. Their studies embody two fundamental problems: a belief that PAF-acether and EPAF are interchangeable and a failure to recognize that PAF is a direct stimulator of activity in the EPF bioassay. As a result, these authors postulated a complex model wherein the refractoriness of PAF-stimulated cells to active factors (S2 factors), produced by them in response to PAF, 


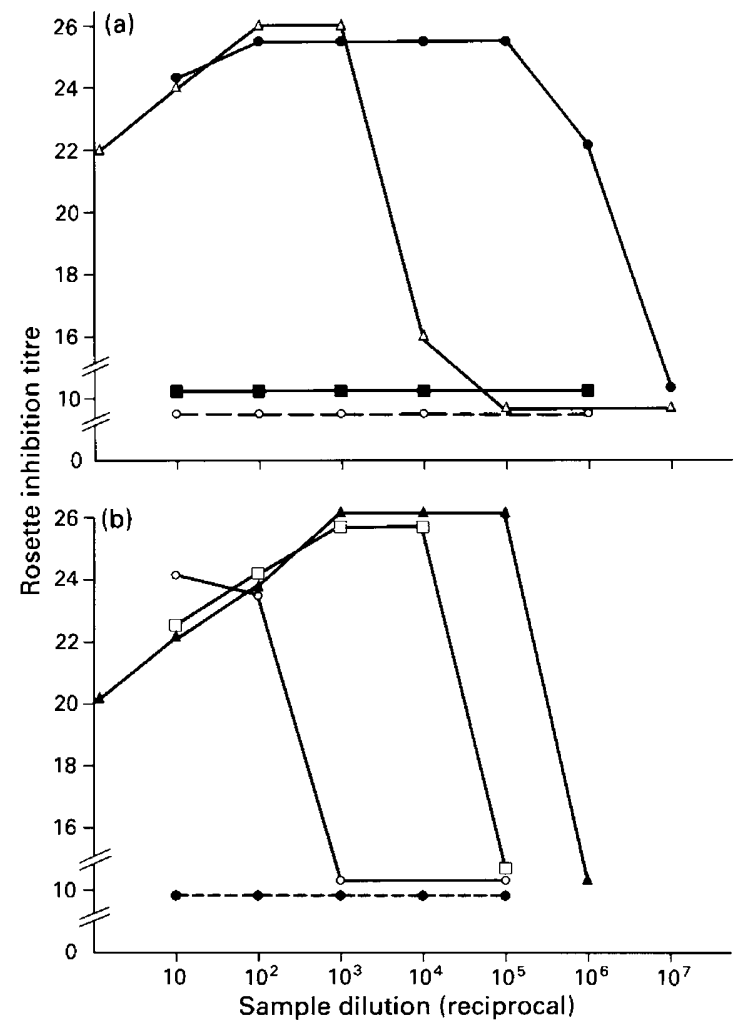

Fig. 5. Activity in the rosette inhibition test of fractions obtained by the 2-step extraction of (a) Day-10 mouse pregnancy serum $\left(10^{-3}, \triangle\right),(\bigcirc)$ lst aqueous, $(\boldsymbol{\square})$ 2nd aqueous and $(O)$ 2nd organic extract serum; and (b) supernatant $S 2$ induced by pregnancy serum $\left(10^{-3}, \boldsymbol{\Delta}\right),(0) 1$ st aqueous, $(\square)$ 2nd aqueous and (๑) 2nd organic extract $\mathbf{S} 2$. Rosette inhibition titres $\geqslant 16$ indicate a positive response.

could be reversed by oestrous serum. As the results in Fig. 4 show, such an explanation is unnecessary; PAF is simply inducing activity in the rosette inhibition test which is susceptible to the action of an oestrous-dependent inhibitor (Cavanagh et al., 1991). However, this inhibitor acts on the initiating signal in the assay rather than on substances induced by it; inhibitory effects are observed, therefore, at the $\mathrm{S} 1$ rather than at the $\mathrm{S} 2$ stage, as seen by Orozco et al. (1990).

Notwithstanding these misapprehensions, the studies by Clarke's group, on the action of PAF in the EPF bioassay, reveal interesting possibilities. This is best appreciated by considering the rosette inhibition test according to our current understanding, using these authors' terminology. The cell pellet P1, produced by incubation of spleen cells with pregnancy serum or its active constituent EPF, after washing to remove the inducing stimulus, provides the ALS-enhancing effect measured by the bioassay (Morton et al., 1976). Rolfe et al. $(1988,1989)$ have shown that, at this point, the active agents are soluble suppressor factors produced in response to pregnancy serum or EPF by a small population of cells in the spleen cell suspension. By incubating P1 in HBSS alone for a further $0.5 \mathrm{~h}$ and collecting the subsequent supernatant S2, Orozco et al. (1990) and Clarke $e t$ al. (1990) removed the inducing signal (EPF) and collected suppressor factors and any soluble mediators produced in response to them. The extraction studies of Clarke et al. (1990) suggest that leukotrienes might be among these latter factors, consistent with the implication of these lipids in suppressor cell circuits (Parker, 1987). The extraction studies confirm this possibility and provide strong support for the proposition that the leukotriene-like activity extracted by Clarke et al. (1990) 
is downstream of the initiating signal of pregnancy serum or EPF. When pregnancy serum was extracted directly, all activity appeared in the first aqueous phase where proteins partition. In contrast, when $\mathrm{S} 2$ produced by pregnancy serum was extracted, activity appeared also in the second aqueous phase. Thus, it is only by exposing spleen cells to EPF in vitro that the leukotriene-like activity is detected.

That effector molecules like leukotrienes can mimic the action of pregnancy serum or EPF when tested with fresh spleen cells is hardly surprising. As has been demonstrated and discussed extensively (Rolfe et al., 1988, 1989; Cavanagh et al., 1991), the rosette inhibition test embodies a complex cascade of events driven by specifically activated spleen cells; mediators at any point may be used to short-circuit the cascade. For example, cyclic adenosine monophosphate (cAMP) appears to act as second messenger in EPF-induced release of suppressor factor; thus cAMP can substitute for EPF in the bioassay, as can the nonspecific lymphocyte activator concanavalin $A$, which also stimulates suppressor release (Rolfe et al., 1988). The ultimate point of identifying these substances and sequences of events is to determine their relevance in vivo. Investigations with monoclonal antibodies to EPF have determined that EPF is required for successful establishment of pregnancy (Athanasas-Platsis et al., 1989). Whether the EPF-induced suppressor factors, whose presence in vivo has been demonstrated (Morton, 1984), and the leukotriene-like species, detected to date in vitro, are important elements in this process is the critical question which further studies must address.

There are two important consequences of these investigations with platelets. The first concerns technical aspects of the EPF bioassay. Since the assay can discriminate between pregnancy and nonpregnancy sera, published methods for serum collection may be adequate, but this is clearly an uncontrolled variable capable of producing false positives through platelet activation; alternative methods of sample collection, such as citrated plasma, are worthy of investigation. In addition, although routine use of platelet-depleted spleen cells for the bioassay would be unacceptably laborious, it may be necessary when testing samples suspected of containing platelet activators.

The second corollary, the secretion of an EPF-like substance from activated platelets, may have far-reaching implications in understanding the biological significance of EPF. One of the earliest events in the inflammatory response is the aggregation and degranulation of platelets with release of numerous inflammatory mediators, including growth factors such as transforming growth factor $\beta$ and platelet-derived growth factor (Whal et al., 1989). EPF displays both growth regulatory (Quinn et al., 1990) and immunomodulatory properties (Noonan et al., 1979; Rolfe et al., 1983, 1988) and its presence in a milieu of factors with similar properties, which are intimately involved in the initiation and maintenance of a localized inflammatory response and in wound healing and tissue repair, may provide the key to understanding its biological role.

The link between EPF and platelets established by these studies is fertile ground for further investigation, yet the initial question, the relationship between EPAF and ovum factor, remains unaddressed. Nevertheless, the studies have determined that this cannot be approached through the use of synthetic PAF. Not only does PAF behave differently from EPAF in the EPF bioassay but also it induces in-vitro artefacts which confound rather than clarify the issue. Whether the EPAF and EPF systems are linked remains an open question; its solution may provide invaluable information about very early events in mammalian pregnancy.

We thank J. Corcoran for typing the manuscript and B. Maher for the graphics.

\section{References}

Amiel, M.L., Duquenne, C., Benveniste, J. \& Testart, J. (1989) Platelet aggregating activity in human embryo culture media free of PAF-acether. Hum. Reprod. 4, 327-330.

Athanasas-Platsis, S., Quinn, K.A., Wong, T-Y., Rolfe, B.E., Cavanagh, A.C. \& Morton, H. (1989) Passive immunization of pregnant mice against early pregnancy factor (EPF) causes loss of embryonic viability. J. Reprod. Fert. 87, 495-502.

Cavanagh, A.C. (1984) The production in vitro of mouse early pregnancy factor and purification to homogeneity. J. Reprod. Fert. 71, 581-592. 
Cavanagh, A.C., Morton, H., Rolfe, B.E. \& Gidley-Baird, A.A. (1982) Ovum factor: a first signal of pregnancy? Am. J. Reprod. Immunol. 2, 97-101.

Cavanagh, A.C., Morton, H., Athanasas-Platsis, S., Quinn, K.A. \& Rolfe, B.E. (1991) Identification of a putative inhibitor of early pregnancy factor in mice. J. Reprod. Fert. 91, 239-248.

Clancy, R.M. \& Hugli, T.E. (1983) The extraction of leukotrienes $\left(\mathrm{LTC}_{4}, \mathrm{LTD}_{4}\right.$ and $\left.\mathrm{LTE}_{4}\right)$ from tissue fluids: the metabolism of these mediators during IgEdependent hypersensitivity reactions in lung. Anal. Biochem. 133, 30-39.

Clarke, F.M., Orozco, C., Perkins, A.V. \& Cock, I. (1990) Partial characterisation of the PAF-induced soluble factors which mimic the activity of 'early pregnancy factor'. J. Reprod. Fert. 88, 459-466.

Clay, K.L., Johnson, C. \& Henson, P. (1990) Binding of platelet-activating factor to albumin. Biochem. Biophys. Acta 1046, 309-314.

Edwards, R.G. \& Gates, A.H. (1959) Timing of the stages of the maturation divisions, ovulation, fertilisation and the first cleavage of adult mice treated with gonadotrophins. J. Endocr. 18, 292-304.

Morton, H. (1984) Early pregnancy factor (EPF): a link between fertilization and immunomodulation. Aust. J. Biol. Sci. 37, 393-407.

Morton, H., Hegh, V. \& Clunie, G.J.A. (1974) Immunosuppression detected in pregnant mice by rosette inhibition test. Nature, Lond. 249, 459-460.

Morton, H., Hegh, V. \& Clunie, G.J.A. (1976) Studies of the rosette inhibition test in pregnant mice: evidence of immunosuppression? Proc. R. Soc. Lond. B 193, 413-419.

Morton, H., Rolfe, B.E., McNeill, L., Clarke, P., Clarke, F.M. \& Clunie, G.J.A. (1980) Early pregnancy factor: tissues involved in its production in the mouse. $J$. Reprod. Immunol. 2, 73-80.

Morton, H., Rolfe, B.E., \& Cavanagh, A.C. (1987) Ovum factor and early pregnancy factor. In Current Topics in Developmental Biology, vol. 23, pp. 73-92. Eds A. McLaren \& G. Siracusa. Academic Press, San Diego.

Noonan, F.P., Halliday, W.J., Morton, H. \& Clunie, G.J.A. (1979) Early pregnancy factor is immunosuppressive. Nature, Lond. 278, 649-651.

O'Neill, C. (1985a) Thrombocytopenia is an initial maternal response to fertilization in mice. J. Reprod. Fert. 73, 559-566.

O'Neill, C. (1985b) Examination of the causes of early pregnancy-associated thrombocytopenia in mice. $J$. Reprod. Fert. 73, 567-577.

O'Neill, C. (1985c) Embryo derived platelet activating factor. In Early Pregnancy Factors, pp. 261-266. Eds F. Ellendorff \& E. Koch. Perinatology Press, New York.
Orozco, C., Perkins, A.V. \& Clarke, F.M. (1986) Plateletactivity factor induces the expression of early pregnancy factor activity in female mice. $J$. Reprod. Fert. 78, $549-555$.

Orozco, C., Cock, I., Perkins, A.V. \& Clarke, F.M. (1990) Platelet-activating factor and serum components from oestrous mice co-operate to mimic the activity of 'early pregnancy factor' in the rosette inhibition assay. J. Reprod. Fert. 88, 447-457.

Parker, C.W. (1987) Lipid mediators produced through the lipoxygenase pathway. Ann. Rev. Immunol. 5, 65-84.

Quinn, K.A., Athanasas-Platsis, S., Wong, T-Y., Rolfe, B.E., Cavanagh, A.C. \& Morton, H. (1990) Monoclonal antibodies to early pregnancy factor perturb tumour cell growth. Clin. exp. Immunol. 80, 100-108.

Rolfe, B.E., Morton, H. \& Clarke, F.M. (1983) Early pregnancy factor is an immunosuppressive contaminant of commercial preparations of human chorionic gonadotrophin. Clin. exp. Immunol. 51, 45-52.

Rolfe, B.E., Cavanagh, A.C., Forde, C., Bastin, F., Chen, C. \& Morton, H. (1984) Modified rosette inhibition test using mouse lymphocytes for detection of early pregnancy factor in human serum. $J$. immunol. Methods 70, 1-11.

Rolfe, B.E., Cavanagh, A.C., Quinn, K.A. \& Morton, H. (1988) Identification of two suppressor factors induced by early pregnancy factor. Clin. exp. Immunol. 73, 219-225.

Rolfe, B.E., Quinn, K., Athanasas, S., Cavanagh, A.C. \& Morton, H. (1989) Genetically restricted effector molecules released by human lymphocytes in response to early pregnancy factor. Immunol. Cell Biol. 67, $205-208$.

Rugh, R. (1968) In The Mouse: Its Reproduction and Development, pp. 38-39. Burgess Publishing Company, Minneapolis.

Smal, M.A., Dziadek, M., Cooney, S.J., Attard, M. \& Baldo, B.A. (1990) Examination for plateletactivating factor production by preimplantation mouse embryos using a specific radioimmunoassay. J. Reprod. Fert. 90, 419-425.

Sueoka, K., Dharmarajan, A.M., Miyazaki, T., Atlas, S.J. \& Wallach, E.E. (1988) Platelet activating factorinduced early pregnancy factor activity from the perfused rabbit ovary and oviduct. Am. J. Obstet. Gynecol. 159, 1580-1584.

Whal, S.M., McCartney-Francis, N. \& Mergenhager, S.E. (1989) Inflammatory and immunomodulatory roles of TGF- $\beta$. Immunology Today. 10, 258-261.

Received 7 September 1990 